\title{
Governance and administration in Sri Lanka: trends, tensions, and prospects
}

\author{
Ramesh Ramasamy
University of Peradeniya, Peradeniya, Sri Lanka \\ Ramesh Ramasamy
University of Peradeniya, Peradeniya, Sri Lanka
}

\begin{abstract}
Purpose - The purpose of this paper is to examine the status of governance and administration in Sri Lanka in light of current crises and the impact on the quality of governance.

Design/methodology/approach - The mixed method approach is employed to explore the problem based on secondary data and results from two major surveys.

Findings - This paper shows political and administrative commitment and quality of governance are two basic ingredients for rapid development and fighting administrative malpractices. Sri Lanka's system of governance is a mixture of paternalism and alliance developed through political dynasty, kinship, ethnicity, caste, religion, and elitism.

Originality/value - This study fills the research gap as few studies have examined the recent crises of Sri Lanka's governance and the impacts on governance quality.

Policy implications - Only by implementing administrative and policy reforms will not improve governance quality in the absence of strong political and bureaucratic commitment. Moreover, global anti-corruption measures are unlikely to work in the Sri Lankan context.
\end{abstract}

Keywords Governance, Public administration, Corruption, Quality of governance, Sri Lanka

Paper type Research paper

\section{Introduction}

This paper examines contemporary issues of governance and administration in Sri Lanka. It focuses on current trends and crises in governance and its impact on institutional quality. The paper argues that the two key requirements for development in any country are political stability and quality governance. Over the last two decades, 'governance' has come to be considered as a core development problem in many developing countries, and they are unable to exercise effective, accountable, impartial, and transparent public authority (Institute of Development Studies, 2010, p. 5). Fukuyama (2013, p. 4) defines governance as "a government's ability to make and enforce rules, and to deliver services, regardless of whether that government is democratic or not." In the past decades, the quest for better and sound governance has been on the policy agenda of governments in Sri Lanka, but the indicators continued to show poor performance. Various reforms, institutional changes and policies have attempted to improve and streamline the governance process at all levels. Despite these experiments and efforts, governance and administration continue to remain unresponsive, unaccountable, non-transparent, unfair, centralized, and rigid (Haque, 2001; Transparency International, 2019; Bandara, 2013; Jamil et al., 2013). This pattern has led to wicked issues, including corruption, poor service delivery, poor quality of public institutions, and political interference in the implementation process. It was during the British rule that a modern administrative system was introduced in Sri Lanka, aiming at depersonalization of public

(C) Ramesh Ramasamy. Published in Public Administration and Policy. Published by Emerald Publishing Limited. This article is published under the Creative Commons Attribution (CC BY 4.0) license. Anyone may reproduce, distribute, translate and create derivative works of this article (for both commercial and non-commercial purposes), subject to full attribution to the original publication and authors. The full terms of this license may be seen at http://creativecommons.org/licences/by/4.0/legalcode

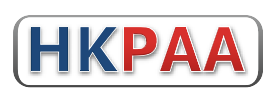

Received 30 March 2020

Revised 27 April 2020

Accepted 4 June 2020 
PAP

23,2

188

service and loyalty to an office rather than to a person (Bandara, 2013, p. 475; Warnapala, 1974; Leitan, 1979).

The administrative system in Sri Lanka has five levels of governance structures - national, provincial, district, divisional, and village, and they function under a strong centralized system. The prevailing multi-level governance structures have resulted in complexities and crises in governance and administration. The reforms introduced in the 1970s and 1980s with the support of IMF and the World Bank with the view of improving public sector performance and efficiency were never realized in practice, and eventually, it became a source of corruption, nepotism, and rent-seeking (Samaratunga and Pillay, 2011, p. 5; de Alwis, 2013; Haque, 2001; Liyanage et al., 2018). This has considerably affected social rights of Sri Lankans. Although successive governments placed high priority on service delivery, it is evident that the quality of goods and services in terms of access, equity, efficiency, and sustainability has progressively deteriorated (ADB, 2004, p. 15).

A considerable number of studies have examined public administration in Sri Lanka and focused on its history, development, structures, and reforms (Bandara, 2013; de Alwis, 2013; Nanayakara, 2015; Somasundaram, 1997; Warnapala, 1974; Samaratunga and Pillay, 2011, Haque, 2001). Few of these studies have documented recent changes and patterns of governance and administration, and there is scant evidence of examining the contemporary governance crisis in Sri Lanka. This paper intends to fill the gap in the literature. Governance related issues deserve serious consideration as there is limited research on context-specific testing and redefining of governance (Samaratunge and Pillay, 2011; Gunapala, 2000). This paper explores the reasons for the low quality of performance and weak integrity of governance institutions, in spite of several efforts for improvement in post-independence Sri Lanka.

This paper is based on a mixed-method approach (Creswell, 2014). It uses a large volume of secondary sources together with two survey results. The first one is the Citizens' Trust in Political and Public Institutions of Sri Lanka carried out in 2015 under The Norwegian Programme for Capacity Development in Higher Education and Research for Development (NORHED) project on Policy and Governance Studies in South Asia with 1,500 respondents from 12 districts of Sri Lanka. The second is the Global Corruption Barometer Survey for Sri Lanka undertaken in 2019 by Transparency International in nine provinces with 1,300 respondents. The qualitative evidence gathered from secondary sources is used to substantiate quantitative data. The second section discusses the theoretical standpoints, and the third analyses governance performance and political implications. The fourth section explores the issues of corruption and the quality of governance, followed by concluding remarks and policy implications.

\section{Changing face of governance}

Although the concept of governance has been widely discussed among policymakers and scholars, there is no strong consensus around a single definition of governance and institutional quality (Kaufmann et al., 2010, p. 2; Fukuyama, 2016, p. 90). Kaufmann and Kraay (2002, p. 5) described "governance as the traditions and institutions by which authority in a country is exercised". They included three dimensions: (1) the process by which governments are selected, monitored, and replaced, (2) the capacity of the government to formulate and implement sound policies effectively, and (3) the respect of citizens and the state for the institutions that govern economic and social interactions among them. The second dimension is much relevant in measuring the quality of governance, which includes the indicators of government effectiveness and regulatory quality. The former captures the perceptions of the quality of public services and civil service and the degree of its independence from political interference, the quality of policy formulation and 
implementation, and the credibility of the government's commitment to such policies. The latter covers the ability of the government to formulate and implement sound policies and regulations (Kaufmann et al., 2010, p. 3). The third dimension highlights the rule of law and control of corruption. Rose-Ackerman defines corruption as the 'misuse of public power for private and political gain.' She views it as a symptom that something has gone wrong in the management of the state and institutions that were designed to govern the interrelationship between citizen and state. Instead, it is used for personal enrichment and the provision of benefits to the corrupt $(1999$, p. 9).

Holmberg and Rothstein (2012) argue that various development outcomes including per capita GDP growth are strongly correlated with the quality of the state services, institutions and government than democracy. Similarly, it is argued that citizens' satisfaction on government and service provision is strongly correlated with the quality of government and bureaucracy (Dahlberg and Holmberg, 2014). Holmberg et al. (2009, p. 145) provide statistical evidence that subjective health, GDP per capita, GDP growth, social security, happiness, and life satisfaction all have positive correlation with the quality of governance. Fukuyama shows the growing significance of transparency and citizen participation in governance as the mechanism for improving institutional performance by highlighting the Open Government Partnership and Extractive Industries Transparency Initiative. This is derived from principal-agent theory to hold politicians and bureaucrats accountable to citizens/voters (2016, p. 93).

Rothstein (2011), Rothstein and Teorell $(2008,2012)$ and Holmberg et al. (2009) support the new concept of Quality of Government (QoG) that indicates how high quality of government can offer the benefits of economic growth and social development. They argue that democracy is primarily concerned with access to government power, but QoG goes beyond that. Further, weak economic growth and corruption are outcomes of the low quality of government institutions, which exercise and implement policies and laws (Acemoglu et al., 2001; Knack and Keefer, 1997; Mauro, 1995). The QoG ideas seem to have a significant impact on noneconomic variables, including subjective human-wellbeing, happiness, satisfaction, fairness, integrity, accountability, responsiveness and transparency.

Huther and Shah (2005) stated that "governance is a multifaceted concept encompassing all aspects of the exercise of authority through formal and informal institutions in the management of the resource endowment of a state. The quality of governance is thus determined by the impact of the exercise of power on the quality of life enjoyed by its citizens (cited in Rothstein and Teorell, 2008, p. 170). Thus, QoG is achieved when government officials do not take into consideration anything that is not stipulated in the policy and the law while implementing laws, policies and programs," (Rothstein and Teorell, 2008, p. 170; Rothstein and Teorell, 2012, p. 25). Studies demonstrate that it is more likely to decrease corruption and increase citizen trust in the government, officials, and political actors when QoG principles are upheld. This, in turn, provides legitimacy for the political system and government policies.

Werlin (2003) argues that developing countries suffer more from inadequate governance than inadequate resources. Hope (2009) suggests that developing countries need to strengthen governance in their countries to overcome critical problems such as corruption and poverty. Generally, governance in developing countries is challenged by ethno-social fragmentation and divisions and they operate in the context of multiple stakeholders, fragmentation and vested interests. In developing countries, centralization, authoritarianism, hierarchy and inflexibility provides limited scope for diverse actors to take part in policymaking and implementation (Samaratunge and Pillay, 2011, p. 391; Narayan et al., 2000).

Haque (2001, pp. 1423-1424) stresses that negative perception regarding the performance and integrity of political and administrative institutions can adversely affect people's trust in 
PAP

23,2

190

governance and legitimacy. It is fair to argue that low quality of governance coupled with rampant corruption seems to have a greater impact on growth, social and human development of developing countries (Holmberg et al., 2009; Akcay, 2006; Kaufmann, 2004). This theoretical framework will help explain the state of governance in Sri Lanka by highlighting institutional decay, excessive politicization, corruption and quality. Institutional trust was measured based on the following question: "I am going to name a number of organizations and institutions. For each one, could you tell me how much confidence you have in them?" We measured the quality of governance and corruption based on citizens' views on the trustworthiness of public officials and attributes such as impartiality, neutrality, fairness, benevolence, helpfulness, responsiveness, and honesty.

\section{Governance performance: political impact and implications}

Despite the introduction of NPM reform-measures in public administration in Sri Lanka, the implementation of many policies reflects the feature of patron-client relationships. This is a common pattern in South Asia, where paternalism and informal relations are closely connected and have deeply entrenched in governance (Jamil et al., 2015, p. 2; Haque, 2001, p. 1406). The reformers' major concerns have been to improve the quality of governance through public-sector efficiency and efficacy, to make the sector more responsive to citizens' demands and aspirations, to reduce public expenditures, and to enhance political and administrative accountability (Christensen and Lægreid, 2011, p. 1). Although Sri Lanka remains in a better position in terms of human development, the nation is still poorly managed (ADB, 2014). Public policymaking does not reflect citizens' interests, and public officials are not held accountable for their actions. Governance performance based on indicators published by the World Bank and Transparency International, Sri Lanka lags far behind on many issues as illustrated in Table 1. These create daunting challenges to Sri Lanka, which has experienced three decades of violent conflict and authoritarian rule in the past.

Sri Lanka is placed in the midrange between 40th and 55th percentile ranks for all indicators for the period covered in this table, except for voice and accountability. In terms of the WWGI ratings, Sri Lanka scored reasonably well on the rule of law, but poorly in control of corruption, political stability, and the absence of violence. Notably, political instability has

Table 1.

Sri Lanka's scores in Human Development Index, Corruption Perception Index, and World Bank's

Worldwide Governance Indicators, 2014-2018

\begin{tabular}{lccccc}
\hline Indicators & 2014 & 2015 & 2016 & 2017 & 2018 \\
\hline Human Development Index (HDI) (value) & 0.77 & 0.77 & 0.77 & 0.78 & 0.78 \\
Corruption Perception Index (CPI) (score) & 38 & 37 & 36 & 38 & 38 \\
Worldwide Governance Indicators (WWGI) (score) & 56.25 & 53.37 & 51.44 & 48.08 & 45.19 \\
Governance effectiveness & 28.08 & 36.45 & 43.35 & 43.35 & 46.80 \\
Voice and accountability & 34.29 & 50.48 & 46.67 & 42.38 & 40.48 \\
Political stability and absence of violence & 50.48 & 51.92 & 51.44 & 50.48 & 47.12 \\
Regulatory quality & 50.00 & 57.69 & 58.17 & 55.29 & 55.57 \\
Rule of law & 44.71 & 45.19 & 46.67 & 41.35 & 43.27 \\
Control of corruption & &
\end{tabular}

Note: Low score means a high incidence of corruption. The scoring system ranges between 0 (public sector perceived as highly corrupt) to 100 (public sector perceived as very clean). According to the 2019 CPI results, Sri Lanka is ranked 93 out of 180 countries with a score of 38 . HDI is a composite index measured based on three dimensions such as long and healthy life, knowledge and a decent standard of living, and it ranges between 0-1. 1 is the most developed country. The WWGIs shows the percentile ranks range between $0-100$ where higher values corresponding to better outcomes on the six indicators.

Source: Transparency International (2020); The World Bank (2019) 
become a prominent feature of Sri Lanka's politics since 2015, and religious violence that took place in 2017/18 further aggravated the problem. There was an improvement in the areas of accountability and voice during 2016-2018, but no significant change in controlling corruption. This indicates a conundrum in corruption research and questions the impact of the rule of law in corruption control. Government effectiveness was affected due to political instability, violence and massive corruption. However, the perception of the quality of governance in the country has hardly changed, although Sri Lanka is positioned in the mid-range in WWGIs, CPI, and Global Competitiveness Index.

Considering the performance in governing and indicators for Sri Lanka, governance reforms have had minimal impact due to deep-rooted institutional crisis and decay. Institutional, legal, and policy loopholes are inimical to governance because of the influence of paternalism in policymaking, which is common in developing countries (Haque, 2003). It may also be argued that the performance or impact of governance-related reforms carried out through policy and institutional-based programs have been uneven.

In Sri Lanka, changes of government significantly influence the continuity of governance related policies. Since independence, two major political parties (United National Party and Sri Lanka Freedom Party) with rival political and economic ideologies ruled the country. Policy measures for improving governance by one party are not likely to be continued after a change of government. With the introduction of the system of proportional representation in 1978, the size of government and the number of ministries expanded to secure support and satisfy political allies. Many of these ministries have overlapping responsibilities and remain fragmented with unclear mandates, roles, and functions.

Furthermore, opposition from political parties, trade unions, and stakeholders remain an obstacle to restructuring and improving governance. This does not apply only to Sri Lanka, but also to other developing countries which are striving to enhance governance quality (Samaratunge and Pillay, 2011). Apparently, the administrative culture remains powerful and deeply rooted in these countries where informal norms and values encourage malpractices, with complete disregard for formally established procedures (Baniamin et al., 2019). This context calls for institutional revolutions because reforming policies and programs are unlikely to result in major changes due to the deep-rooted culture of paternalism. In the case of Sri Lanka, informal norms, relations, and values become the rule of the game, and they cut through all bottlenecks to protect vested interests. Moreover, paternalism is an aspect of informal relations. According to Schick (1998, p. 128), "informality is a mixed blessing. On the one hand, it cuts through red tape, unresponsive bureaucracies, and bad policies; on the other hand, it opens the door to (sometimes institutionalizes) corruption and inefficiency."

Almost all governments in the recent past came to power with the promise of reforms to improve the quality of governance, make institutions more transparent, accountable to the people, and less susceptible to corruption. The Ten-Year Horizon Development Framework (2006-2016) of Mahinda Rajapaksa's government highlighted inefficiency and the need for improvement in the public administration system in several sections of their policy manifesto, including accountability and transparency (ADB, 2007, p. 4). It was expected that this strategy would help reorient public service, minimize procedural delays and structural inefficiencies in public institutions, and generate responsiveness to the demand for quality services. In reality, these promises were not materialized in a manner to help enhance the quality of governance and building citizens' trust in government.

This pattern was confined to not only the incumbent regime but also the subsequent government that came to power in 2015. The government itself came up with several policy possibilities to eradicate corruption and improve governance by establishing presidential commissions and other institutional structures to investigate various forms of corruption. The constitutional amendment, widely known as the $19^{\text {th }}$ amendment, became instrumental during this period in improving governance, though it was not operationalised effectively. 
Despite these positive changes, high profile corruption was evident shortly after the government touting good governance came to office in 2015.

The amendment reduced the powers of the President in the affairs of public service by establishing independent commissions, Constitutional Council and enacting the right to information act. It was expected that all these changes would enhance governance quality, and the WWGIs and CPI also showed marginal improvement in many areas of governance during 2015-2017, but these were not sustained. The incumbent government (after the regime change in November 2019), headed by former military personnel, is more likely to reform governance structures with the objective of concentrating powers in the hands of the executive. Military personnel are deployed in the public institutions to oversee the work of public officials. Generally, actions of this nature lead to administrative-military conflict in service delivery and policy management. It seems that the government is inclined towards using a militaristic approach to civil service administration and governance (Uyangoda, 2020) and this could lead to a form of governance based on authoritarianism together with paternalism. Although there was a high turnover in electoral participation (70-75\%), it had little impact on improving democratic governance. This shows how political regime influence in shaping governance in developing countries.

The most acclaimed aspect of the $19^{\text {th }}$ amendment is the enactment of the long-awaited Right to Information Act (RTI). Three years after its implementation, the Act continues to remain as an example of the transformative impact of progressive and pro-citizen legislation, despite persisting challenges. The RTI commission makes a useful contribution to the implementation of the Act with limited institutional capacity. It has achieved progress regarding citizens' demands for information and declaration of assets by senior politicians, and many people have benefitted from this legislation. It is too early to assess the impact of these changes in governance indicators and institutional performance. Nevertheless, the Canadian Centre for Law and Democracy considers Sri Lanka's RTI as one of the most robust legislations in the world, and ranked Sri Lanka's RTI third in 2017 and fourth in 2018 in a list of 80 countries. However, this evaluation is based largely on the content of the Act, and not its implementation and impact. The law provides wider avenues for citizens to access a range of information held under the custody of public institutions, subject to certain limitations, and it helps in changing the long-standing culture of secrecy in public institutions. Without a functional democracy, the right to information may remain mere rhetoric, reflecting symbolic politics. Based on Sri Lanka's experience, it can be argued that institutional and policy innovations, reforms, and revolutions are extremely challenging in developing societies as the political changes and interests continue to influence policy choices and decisions. Further, reforms are less likely to be put into actions or practice, if they go against the existing administrative systems, informal working norms, privileges, interests that both political actors and bureaucrats have had been enjoying for a very long period.

The introduction of proportional representation in the constitution, have increased the visibility of elected public servants in policy implementation. Theoretically, policy implementation involves a series of managerial activities following policy formulation, and the former is considered to be the domain of appointed or elected public servants who are career professionals. However, elected representatives head the executive arm of the government. The direct intervention of elected representatives in policy implementation amounts to a biased administrative process (Gammampila, 1997, p. 319). It is argued that political control of the administrative process is necessary because political leaders are directly answerable to citizens, especially in matters of development and welfare. Failure or ineffectiveness of the legislative policy implementers or public officials also forced elected officials to intervene in issues related to service provision, which is a new development in Sri Lanka. This pattern led to undue political influence and politicization in the policy implementation process, and political actors were able to use public power for vested interests. 


\section{Corruption, institutional performance and governance quality}

Empirical evidence indicates that Sri Lankans bribe public officials and politicians for three main reasons: (a) to receive a service entitled to; (b) to avoid a problem with the authorities that provide various services; and (c) to speed up things. Interestingly, more than $50 \%$ pay bribe to speed up things. According to the Global Corruption Barometer for Sri Lanka (Transparency International, 2019, p. i), only around 47\% trust the government, which means half of the respondents did not do so. Likewise, the Governance and Trust Survey (GoT Survey) (NORHED, 2015) showed very similar results. Approximately 80\% consider corruption in the government to be a huge problem. The GCBSL survey indicates a rapid increase in corruption in areas related to climate change, natural resource utilisation, and disaster management and $51 \%$ of the respondents believe that corruption is rampant in these sectors. This is a new development in Sri Lanka, and large-scale scandals were reported in the areas of environment and natural resource management involving political leaders and officials. It has now gained increased attention as Sri Lanka has become a disaster-prone country over the past few decades. The survey reasserted that corruption has become a permanent feature in public and political institutions and a way of life among the poor segments of society where they have to bribe officials to get what they need.

Poor people suffer from indifferent treatment if they fail to bribe, even in needs-tested selective welfare programs such as poverty alleviation, relief distribution during an emergency, social security benefits, and housing. Several studies confirm this pattern in many developing countries (Persson et al., 2013; Rothstein and Uslaner, 2016; Baniamin and Jamil, 2018). Rationality based on the principles of neutrality, universality, impartiality, formalization, procedural justice, and equality before the law has not taken deep root in the South Asian countries, unlike in the West. This is precisely the case in Sri Lanka, where "strong loyalties toward family, ethnic groups, religion, caste, kinship, and people from the same region or political party is prominent, instead of rationality" (Jamil et al., 2013, p. 16). These have become informally accepted eligibility criteria for beneficiary selection and service provision where the poor people and minorities are more likely to be singled out for exclusion in service provision (Persson et al., 2013; Baniamin and Jamil, 2018; Ramesh, 2020).

Seventy-seven percent of the surveyed respondents think that public officials and politicians abuse their power and position to benefit themselves or their families. An interesting finding of the survey is that $9 \%$ had stated that they bribed on the overt request made by officials, and in contrast, as many as $70 \%$ did so voluntarily, and $52 \%$ stated that it was due to an implicit understanding that a bribe is necessary to get their work done or expedited (Transparency International, 2019, pp. i-ii). The GoT Survey shows that only $40 \%$ seem to have trust in parliament and, quite surprisingly, a mere $24 \%$ trust political parties. A similar situation can be observed in the area of citizens' trust in the civil service as well (66\%). Similarly, GoT Survey indicates that Sri Lankans have low trust in the members of several professions, including civil servants $(43 \%)$, central government politicians $(46 \%)$, local politicians $(12 \%)$ and police (19\%). This vindicates that incompetency of public bureaucracy, low quality of governance and institutionalized corruption are two different types of state failure in developing countries (Dhalström et al., 2013, p. 525).

The results of the GoT Survey to assess civil service trustworthiness in Sri Lanka show variations in respondents' perceptions (in percentage) in public officials' behavioural traits: prompt and efficient (37), corrupt (40), serving personal interest (51), helpful and responsive (40), difficult to get access to (43), reliable and trustworthy (35), treat all equally (21), discharging duties based on established procedure and norms (48), work transparently (19), and honest and truthful (22). This explains the quality of bureaucracy and governance - a larger segment of Sri Lankans seems to have little trust in the civil service and are unlikely to perceive them as trustworthy, helpful, benevolent, impartial, politically neutral and responsive. Such perceptions not only distort citizens' institutional trust in public
Governance

and

administration

in Sri Lanka

193 
institutions but may detrimentally affect social trust and social capital. If the governance structures and society are corrupt, people may have valid reasons not to trust their fellow citizens as well (Baniamin et al., 2019; Rothstein and Uslaner, 2016). Gault (2016) and Persson et al. (2013) argue that when a society experiences systematic corruption, it shows the existence of a predictable and persistent social trap that cannot be removed without changing deep-rooted unethical and immoral social practices. When corruption becomes the rule of the game, public institutions become biased and unfair in practice.

In Sri Lanka, the problem of institutional quality became evident when respondents were asked about the effectiveness of the anti-corruption institution. There was a high level of uncertainty and skepticism on the action that would be taken after reporting against institutions for corruption. Interestingly, only $8 \%$ noted that it is very likely that actions will be taken after receiving reports, whereas $47 \%$ believed that it was "somewhat likely". Empirical evidence shows that the level of awareness on the functions and powers of the main anti-corruption agency of the country (Commission on Investigating Allegations of Bribery and Corruption - CIABC) remain low among citizens, and a significant number of respondents noted that they are unaware of the reporting procedure for corruption. Sri Lankans are strongly dissatisfied with CIABC for its role in fighting corruption - around $74 \%$ noted that it is doing fairly badly or very badly in this regard (Transparency International, 2019). The GoT Survey shows that only 55\% of Sri Lankans trust anti-corruption institutions. Empirical evidence indicates four key constraints in fighting corruption in Sri Lanka: (a) sense of fear of reprisals and loss of services and institutional supports; (b) lack of awareness of the procedures for reporting corruption; (c) low level of trust that actions would be taken upon reporting by the anti-corruption agency; and (d) the absence of concerted action to fight corruption.

Quah (1982) argued that the government's effectiveness and sincerity in wiping out corruption not only depend on the formulation of anti-corruption laws, but the actual implementation without partiality that should have some effect on politicians and officials and at the societal level. Despite the passing of the Right to Information Act and the adoption of the Open Government Partnership (OGP) National Action Plan, Sri Lanka is yet to see robust action against corruption. These two crucial policy initiatives came into force in 2015 when Sri Lanka became the only South Asian country to sign the OGP declaration. Fukuyama, (2016, p. 99) believes this to be an initiative enabling citizen/civil society participation in governance and holding public institutions accountable and responsive, and empowering citizens.

The survey found the emergence of a new form of widely prevalent corruption in political and public institutions in Sri Lanka - 'sextortion.' Officials and politicians seek sexual favor in return for services. Based on their own experiences or from cases known to them, some $60 \%$ of respondents noted that public officials implied openly or suggestively that they would grant a benefit in return for a sexual favor (Transparency International, 2019, pp. i-ii). This has serious implications for gender equality and women's access to public institutions to obtain legally mandated services where the institutions are male-dominated and patriarchal. This pattern places marginalized and socially excluded women into an extremely vulnerable position in which they are unfairly and indifferently treated in welfare service provision. According to Pierre and Peters (2000, p. 1), "thinking about governance means thinking about how to steer the economy and society, and how to reach collective goals." Formulating collective goals require the inclusion and participation of people that would allow them to be directly involved in the process of governing, irrespective of all kinds of differences.

It could be argued that anti-corruption measures induced by principal-agent framework appear to help maintain the corrupt system, rather than reporting, punishing corrupt behavior, political leaders and citizens (Persson et al., 2013, p. 454). Any anti-corruption effort without genuine political will and commitment can be unsuccessful will fail, as in the case 
of Sri Lanka. The new regime that came to office in 2015 promised that they would review corrupt and immoral actions of their predecessors and bring them to justice. This was part of the justifications for their claim to power. Unfortunately, their anti-corruption efforts and institutions eventually have become immersed in the same corrupt system that they planned to fight. This becomes evident with high profile corruption scandals that have taken place in this country, including the Central Bank Bond scam (2015) and scandals involving Airbus (2019), Millennium City and MiG deal. This is the case in many developing countries where political leaders and officials often talk about accountability, openness and transparency but do not translate those into practice to detect and penalize corrupt behavior (Persson et al., 2013, p. 455). Many have argued that some countries remain more corrupt than others because public acceptance of what is commonly understood as corruption varies significantly across cultures (Heidenheimer, 2002). This explains that what is considered a bribe in the Western context is simply considered a gift in developing countries with endemic corruption (Rose-Ackerman, 1999; Persson et al., 2013). Since corruption remains a part of the administrative culture in Sri Lanka and it has been informally institutionalized, global anti-corruption packages cannot be expected to succeed in this case. This coincides with Larry Diamond's argument that endemic corruption is not some flaw that can be corrected with a technical fix or political push; it is the way the system works, and it is deeply embedded in the norms and expectations of political and social life (2007, p. 119). Reducing it to less destructive levels and keeping it there requires a revolutionary change in institutions.

\section{Conclusion}

This paper explored contemporary governance crises and administration in Sri Lanka. It suggests that administrative, policy and legal reforms and institutional changes will not improve governance quality, unless strong political and bureaucratic commitment, system stability, and institutional revolutions can be ensured. Sri Lanka's administrative system has undergone several changes without producing major improvements in the governance process. Further, post-independence constitution-making led to the centralization of political power in the hands of the popularly elected political executive that paved the way for undue political influence and bureaucratic politicization. This has reduced most of the reforms into mere cosmetic exercises. As such, Sri Lanka provides a test case to understand the correlation between the political regime, reforms, administrative culture, and its impact on governance.

Policymakers can be aware that the current state of governance and administration in Sri Lanka is primarily shaped by socio-political and historical context, and this has to be appreciated and understood in planning reforms. There is a need for transcending and understanding the narrow definition of public sector performance based on criteria such as efficiency, competition, and revenue. It is necessary to incorporate other dimensions, such as the role of public governance in ensuring the rights and demands and inclusion of all groups in the governance process and addressing social inequality.

Persson et al. (2013) noted that the anti-corruption efforts influenced by the principal-agent theory are unlikely to work in developing countries where corruption is endemic and constitute part of the culture. Each developing society has unique features in the governance process, despite their colonial roots and shared history. These features in the case of Sri Lanka are ethnicity and family, religion and language. Based on the empirical evidence and theoretical discussion, Sri Lanka's form of governance can be described as a mixture of paternalism and alliance making. Traditional major political parties favor paternalism in which they are deeply rooted and impose a cross-cutting effect in all forms of governance due to the long-standing influence of political dynasty, kinship, ethnicity, caste, region, and nationalism. Later, colonial history, the emergence of power politics, and social order resulted in the development of a different form of governance in Sri Lanka. 
PAP

23,2

\section{References}

Acemoglu, D., Johnson, S. and Robinson, J.A. (2001), "The colonial origins of comparative development: an empirical investigation”, The American Economic Review, Vol. 91 No. 5, pp. 1369-1401.

Akcay, S. (2006), “Corruption and human development”, Cato Journal, Vol. 26 No. 1, pp. 29-48.

Asian Development Bank (ADB) (2004), Review of Governance and Public Management for Sri Lanka, Asian Development Bank, Manila.

Asian Development Bank (ADB) (2007), "Sri Lanka country assistance programme: evaluation of thematic governance assistance", Evaluation Working Paper, Asian Development Bank, Manila.

Bandara, N. (2013), "History and context of public administration in Sri Lanka", in Sabharwal, M. and Berman, E.M. (Eds.), Public Administration in South Asia: India, Bangladesh and Pakistan, CRC Press, Boca Raton, pp. 454-471.

Baniamin, H.M. and Jamil, I. (2018), "Institutional design for credence goods: can the existence of financial incentives be problematic? Evidence from the childbirth system of Bangladesh", International Journal of Public Administration, Vol. 41 No. 14, pp. 1192-1203.

Baniamin, H.M., Jamil, I. and Askvik, S. (2019), "Mismatch between lower performance and higher trust in the civil service: can culture provide an explanation?", International Political Science Review, Vol. 41 No. 2, pp. 192-206.

Christensen, T. and Lægreid, P. (2011), "Introduction", in Christensen, T. and Lægreid, P. (Eds.), The Ashgate Research Companion To New Public Management, Ashgate, Farnham, pp. 1-13.

Creswell, J.W. (2014), Research Design: Qualitative, Quantitative and Mixed Methods Approaches, Sage, London.

Dahlberg, S. and Holmberg, S. (2014), "Democracy and bureaucracy: how their quality matters for popular satisfaction”, West European Politics, Vol. 37 No. 3, pp. 515-537.

de Alwis, R.K. (2013), Administrative Reforms in Sri Lanka, Godage Publishers, Colombo.

Dhalström, C., Lindvall, J. and Rothstein, B. (2013), "Corruption, bureaucratic failure and social policy priorities”, Political Studies, Vol. 61, pp. 523-542.

Diamond, L. (2007), “A quarter-century of promoting democracy”, Journal of Democracy, Vol. 18 No. 4, pp. 118-120.

Fukuyama, F. (2013), "What is governance?", Governance: An International Journal of Policy, Administration, and Institutions, Vol. 26 No. 3, pp. 347-368.

Fukuyama, F. (2016), "Governance: what do we know, and how do we know it", Annual Review of Political Science, Vol. 19, pp. 89-105.

Gammampila, M. (1997), "Learning opportunities for elected public servants", in Somasundaram, M. (Ed.), Third Wave: Governance and Public Administration in Sri Lanka, International Centre for Ethnic Studies and Kornak Publishers, Colombo/Delhi, pp. 311-339.

Gault, D.A. (2016), "Understanding the trap of systematic corruption”, Governance: An International Journal of Policy, Administration and Institutions, Vol. 29 No. 4, pp. 463-465.

Gunapala, G.D.C. (2000), "Governance and administration in Sri Lanka", in Hye, H.A. (Ed.), Governance: South Asian Perspectives, University Press Ltd, Dhaka, pp. 203-215.

Haque, S.M. (2001), "Recent transition in governance in South Asia: contexts, dimensions and implications", International Journal of Public Administration, Vol. 24 No. 12, pp. 1405-1436.

Haque, S.M. (2003), "Reinventing governance for performance in South Asia: impacts on citizenship rights", International Journal of Public Administration, Vol. 26 No. 8/9, pp. 941-964.

Heidenheimer, A.J. (2002), "Perspectives on the perception of corruption", in Heidenheimer, A.J. and Johnston, M. (Eds.), Political Corruption: Concepts and Contexts, Transaction Publishers, New Brunswick and London. 
Holmberg, S. and Rothstein, B. (2012), Good Government: The Relevance of Political Science, Edward Elgar, London.

Holmberg, S., Rothstein, B. and Nasiritousi, N. (2009), "Quality of government: what you get", Annual Review of Political Science, Vol. 12, pp. 135-161.

Hope, K.R. (2009), "Capacity development for good governance in developing countries: some lessons from the field", International Journal of Public Administration, Vol. 32 No. 8, pp. 728-740.

Huther, J. and Shah, A. (2005), "A simple measure of good governance", in Shah, A. (Ed.), Public Services Delivery, The World Bank, Washington, DC.

Institute of Development Studies (2010), An Upside Down View of Governance, Institute of Development Studies, Brighton.

Jamil, I., Amiunizzaman, M.S. and Haque, S.T.M. (2015), "Introduction", in Jamil, I., Amiunizzaman, M.S. and Haque, S.T.M. (Eds.), Governance in South, Southeast and East Asia, Springer, New York, NY, pp. 1-10.

Jamil, I., Steinar, A. and Dhakal, T. (2013), "Understanding governance in South Asia”, in Jamil, I., Steinar, A. and Dhakal, T. (Eds.), In Search of Better Governance in South Asia and Beyond, Springer, New York, NY, pp. 13-36.

Kaufmann, D. and Kraay, A. (2002), Growth without Governance, The World Bank, Washington, DC.

Kaufmann, D., Kraay, A. and Mastruzzi, M. (2004), "Governance matters III: Governance indicators for 1996-2002”, The World Bank Policy Research Working Paper, No. 3106, available at: https:// elibrary.worldbank.org/doi/abs/10.1596/1813-9450-3106 (accessed 15 May 2020).

Kaufmann, D., Kraay, A. and Mastruzzi, M. (2010), "The worldwide governance indicators: methodology and analytical issues", The World Bank Policy research working paper, No. 5430, availableat:https://papers.ssrn.com/sol3/papers.cfm?abstract_id=1682130 (accessed 10 March 2020).

Knack, S. and Keefer, P. (1997), "Institutions and economic performance: cross country test using alternative institutional methods", Economics and Politics, Vol. 7 No. 3, pp. 207-227.

Leitan, G.R.T. (1979), Local Government and Decentralized Administration in Sri Lanka, Lake House Investments, Colombo.

Liyanage, K., Ramesh, R. and Sivakumar, N. (2018), "Public administration in Sri Lanka: an inquiry on structures, reforms and management", in Jamil, I., Dhakal, T and Paudel, N. (Eds.), Civil Service Administration and Management in South Asia, Palgrave Macmillan, London, pp. 281-304.

Mauro, P. (1995), “Corruption and growth”, Quarterly Journal of Economics, Vol. 110 No. 3, pp. 681-712.

Nanayakara, V.K. (2015), "Sri Lanka administrative service (1963-2013): a fifty year", Journal of Sri Lanka Institute of Development Administration, Vol. 5, pp. 79-93.

Narayan, D., Patel, R., Schafft, K. and Rademacher, A. (2000), Can Anyone Hear Us?: Voices of the Poor, The World Bank, Washington DC.

Persson, A., Rothstein, B. and Teorell, J. (2013), "Why anticorruption reforms fail -systemic corruption as a collective action problem", Governance: An International Journal of Policy, Administration and Institutions, Vol. 26 No. 3, pp. 449-471.

Pierre, J. and Peters, G.B. (2000), Governance, Politics and the State, Macmillan, New York, NY.

Quah, J.S.T. (1982), "Bureaucratic corruption in the ASEAN countries: a comparative analysis of their anti-corruption strategies", Journal of Southeast Asian Studies, Vol. 13 No. 1, pp. 153-177.

Ramesh, R. (2020), "Quality of government, institutional impartiality and public service delivery in ethnically polarized societies", Asia Pacific Journal of Public Administration, Vol. 42 No. 1, pp. 46-60.

Rose-Ackerman, S.R. (1999), Corruption and Government: Causes, Consequences and Reform, Cambridge University Press, London.

Rothstein, B. (2011), The Quality of Government, Corruption, Social Trust, and Inequality in the International Perspective, University of Chicago Press, Chicago.

Governance and administration in Sri Lanka

\footnotetext{
$+$
} 
PAP

23,2

Rothstein, B. and Teorell, J. (2008), "What is the quality of government: theory of impartial government institutions", Governance, Vol. 21 No. 2, pp. 165-190.

Rothstein, B. and Teorell, J. (2012), "Defining and measuring quality of government", in Holmberg, S. and Rothstein, B. (Eds.), Good Government: The Relevance of Political Science, Edward Elgar, London, pp. 13-40.

Rothstein, B. and Uslaner, E. (2016), “All for all: equality, corruption and social trust”, Working Paper, The Quality of Government Institute, Goteborg.

Samaratunge, R. and Pillay, S. (2011), "Governance in developing countries: Sri Lanka and South Africa compared", International Journal of Public Administration, Vol. 34 No. 6, pp. 389-398.

Schick, A. (1998), "Why most developing countries should not try New Zealand's reforms", The World Bank Research Observer, Vol. 13 No. 1, pp. 123-131.

Somasundaram, M. (1997), "Sri Lanka administrative service”, in Somasundaram, M. (Ed.), The Third Wave: Governance and Public Administration in Sri Lanka, International Centre for Ethnic Studies, Colombo, pp. 340-356.

The Norwegian Programme for Capacity Development in Higher Education and Research for Development (NORHED) (2015), Governance and trust (GoT) Survey in Sri Lanka, Department of Political Science, University of Peradeniya.

The World Bank (2019), "Worldwide Governance Indicators", available at: https://datacatalog. worldbank.org/dataset/worldwide-governance-indicators (accessed 15 May 2020).

Transparency International (2019), "Country data: global corruption barometer in Sri Lanka", available at: https://www.transparency.org/en/countries/sri-lanka (accessed 15 May 2020).

Transparency International (2020), "2019 Corruption Perceptions Index shows anti-corruption efforts stagnating in G7 countries", available at: https://www.transparency.org/en/press/2019-cpiefforts-stagnate-in-g7 (assessed 15 May 2020).

Uyangoda, J. (2020), "A constitutional solution to the impeding constitutional crises", Colombo Telegraph, 30 April, available at: https://www.colombotelegraph.com/index.php/a-constitutionalsolution-to-the-impending-constitutional-crisis/ (accessed 3 May 2020).

Warnapala, W.A. (1974), Civil Service Administration in Ceylon: A Study in Bureaucratic Adaptation, Department of Cultural Affairs, Colombo.

Werlin, H.H. (2003), "Poor nations, rich nations: a theory of governance", Public Administration Review, Vol. 63 No. 3, pp. 329-342.

\begin{abstract}
About the author
Ramesh Ramasamy, $\mathrm{PhD}$, teaches at the Department of Political Science, University of Peradeniya, Sri Lanka at governance, public policy, human rights, development administration and research methodology at both bachelors and postgraduate levels. His research interests are mainly on quality of governance, corruption, institutional trust and minority rights. He has published several peer reviewed journal articles and book chapters, including "Quality of Government, Public Service Delivery and Institutional Impartiality in Ethnically Polarized Societies: Evidence for Policy Makers" (Asia Pacific Journal of Public Administration), Public Administration in Sri Lanka: An Inquiry on Structures, Reforms and Management (Palgrave Macmillan), Party Politics in the Plantation Community of Sri Lanka: Growth and Changes (Oxford University Press). He has coordinated two waves of governance and trust survey in Sri Lanka (2015 and 2020) under NORHED project. Ramesh Ramasamy can be contacted at: ramnaresh45@yahoo.com
\end{abstract}

For instructions on how to order reprints of this article, please visit our website:

www.emeraldgrouppublishing.com/licensing/reprints.htm

Or contact us for further details: permissions@emeraldinsight.com 